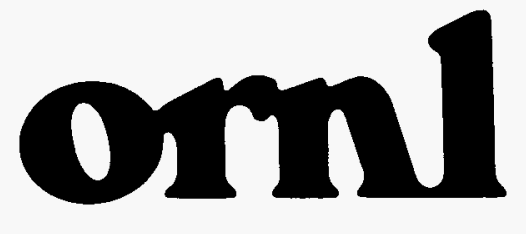

OAK RIDGE

NATIONAL

LABORATORY

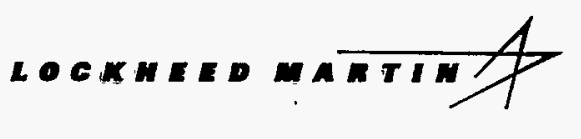

MECENEO

10.82 233

OSTI

\section{Results of the Independent Radiological Verification Survey of the Remedial Action Performed at 525 S. Main Street Oxford, Ohio (OX0002)}

\author{
K. R. Kleinhans \\ D. E. Rice \\ M. E. Murray \\ R. F. Carrier
}

WANAGEDAWD OPERATEDIBY

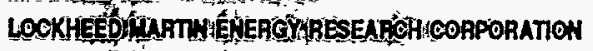
FORTHEOTHEOSTATES

DEPARTIENT OF ENEAGY :

\section{DISCLAIMER}

This report was prepared as an account of work sponsored by an agency of the United States Government. Neither the United States Government nor any agency thereof, nor any of their employees, makes any warranty, express or implied, or assumes any legal liability or responsibility for the accuracy, completeness, or usefulness of any information, apparatus, product, or process disclosed, or represents that its use would not infringe privately owned rights. Reference herein to any specific commercial product, process, or service by trade name, trademark, manufacturer, or otherwise does not necessarily constitute or imply its endorsement, recommendation, or favoring by the United States Government or any agency thereof. The views and opinions of authors expressed herein do not necessarily state or reflect those of the United States Government or any agency thereof. 
This report has been reproduced directly from the best available copy.

Available to DOE and DOE contractors from the Office of Scientific and Techntcal information, P.O. Box 62, Oak Ridge, TN 37831; prices available from (615) 576-8401, FTS 626-8401.

Available to the public from the National Technical Information Service, U.S. Department of Commerce, 5285 Port Royal Rd., Springfield, VA 22161.

This report was prepared as an account of work sponsored by an agency of the United States Government. Neither the United States Government nor any agency thereof, nor any of their employees, makes any warranty, express or implied, or assumes any legal liability or responsibility for the accuracy, completeness, or usefulness of any information, apparatus, product, or process disclosed, or represents that its use would not infringe privately owned rights. Reference herein to any specific commercial product, process, or service by trade name, trademark, manufacturer, or otherwise, does not necessarily constitute or imply its endorsement, recommendation, or favoring by the United States Government or any agency thereof. The views and opinions of authors expressed herein do not necessarily state or reflect those of the United States Government or any agency thereof. 


$$
\text { ORNL/RASA--95/2 }
$$

ORNL/RASA-95/2

HEALTH SCIENCES RESEARCH DIVISION

Environmental Restoration and Waste Management Non-Defense Programs

(Activity No. EX 2020010 )

\title{
Results of the Independent Radiological Verification Survey of the Remedial Action Performed at 525 S. Main Street, Oxford, Ohio (OXO002)
}

\author{
K. R. Kleinhans, * D. E. Rice, M. E. Murray, and R. F. Carrier
}

Date of publication - April 1996

Investigation Team

R. D. Foley-Measurement Applications and Development Manager

M. E. Murray-Radiological Program Director

K. R. Kleinhans* and D. E. Rice-Survey Team Leaders

Survey Team Members
J.F. Allired
R. Lenc $\dagger$
R. A. Mathis
V.P. Patania
A. C. Butler**
D. A. Rose
G. H. Cofer
S. P. McKenzie
D. A. Roberts
R. L. Coleman
R. E. Rodriguez
R. C. Gosslee
P.F. Tiner
R. R. Knott $\dagger$
M. E. Murray
J. Wade
W. Winton
W. A. Williams † $^{\prime}$

*Former employee of Martin Marietta Energy Systems, Inc.

**Midwest Technical, Inc.

†Environmental Technology Section

i†U.S. Department of Energy

Work performed by the

Measurement Applications and Development Group

Prepared by the

OAK RIDGE NATIONAL LABORATORY

Oak Ridge, Tennessee 37831-6285

managed by

LOCKHEED MARTIN ENERGY RESEARCH CORP.

for the

U. S. DEPARTMENT OF ENERGY

under contract DE-AC05-960R22464 



\section{CONTENTS}

LIST OF FIGURES $\ldots \ldots \ldots \ldots \ldots \ldots \ldots \ldots \ldots \ldots \ldots \ldots \ldots \ldots \ldots \ldots \ldots \ldots$

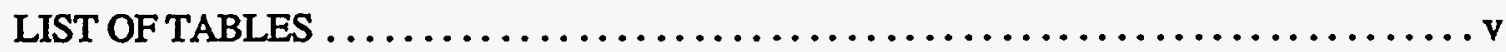

ACKNOWLEDGMENTS $\ldots \ldots \ldots \ldots \ldots \ldots \ldots \ldots \ldots \ldots \ldots \ldots \ldots \ldots \ldots \ldots \ldots$ vii

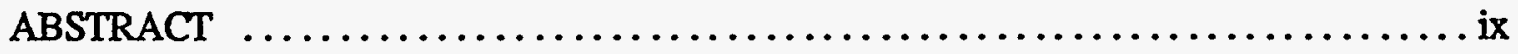

INTRODUCTION $\ldots \ldots \ldots \ldots \ldots \ldots \ldots \ldots \ldots \ldots \ldots \ldots \ldots \ldots \ldots \ldots \ldots \ldots \ldots$

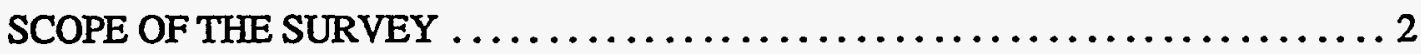

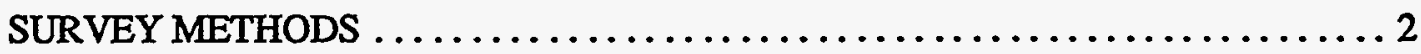

SURFACE RADIATION MEASUREMENTS $\ldots \ldots \ldots \ldots \ldots \ldots \ldots \ldots \ldots \ldots \ldots \ldots$

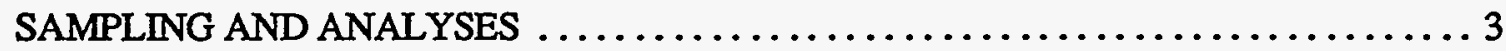

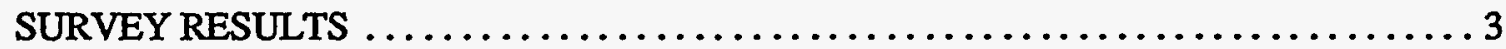

OUTDOOR RESULTS $\ldots \ldots \ldots \ldots \ldots \ldots \ldots \ldots \ldots \ldots \ldots \ldots \ldots \ldots \ldots \ldots$

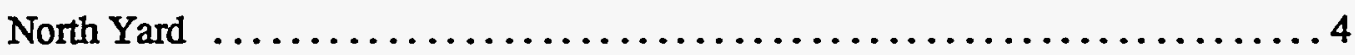

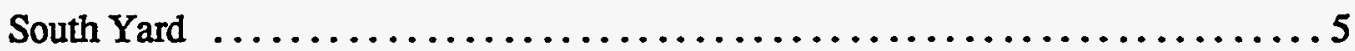

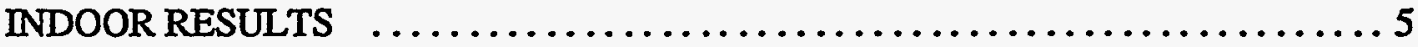

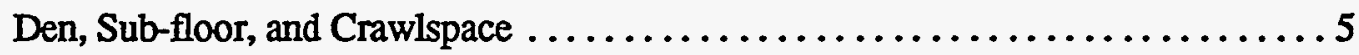

East Bedroom Area $\ldots \ldots \ldots \ldots \ldots \ldots \ldots \ldots \ldots \ldots \ldots \ldots \ldots$

Garage Bathroom $\ldots \ldots \ldots \ldots \ldots \ldots \ldots \ldots \ldots \ldots \ldots \ldots \ldots$

INDOOR RESULTS SUMMARY $\ldots \ldots \ldots \ldots \ldots \ldots \ldots \ldots \ldots \ldots \ldots \ldots$

SIGNIFICANCE OF FINDINGS $\ldots \ldots \ldots \ldots \ldots \ldots \ldots \ldots \ldots \ldots \ldots \ldots \ldots \ldots$

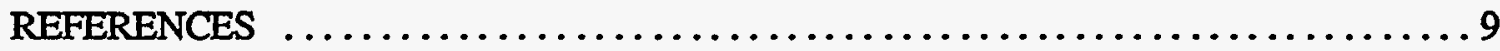





\section{LIST OF FIGURES}

1 Diagram showing the general location of Oxford, Ohio $\ldots \ldots \ldots \ldots \ldots \ldots \ldots \ldots$

2 Diagram showing the general location of the former Alba Craft Laboratory site

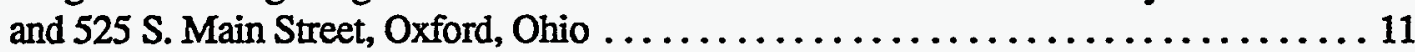

3 Diagram showing the layout of the residential property at $525 \mathrm{~S}$. Main Street and the

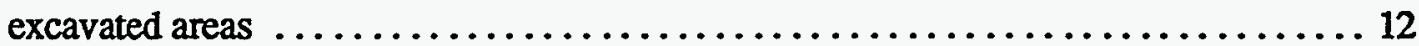

4 Diagram showing grid and locations of soil samples collected from the North Yard

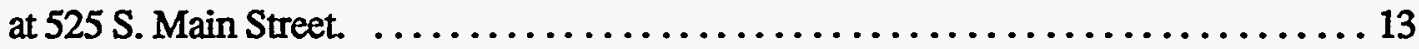

5 Diagram showing grid and locations of soil samples collected from the South Yard

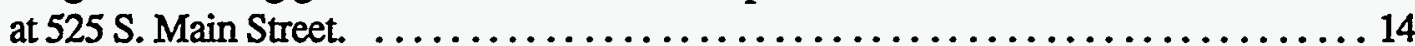

6 Photograph showing excavated areas in the north yard on each side of

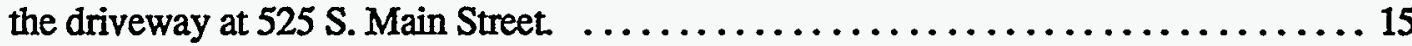

7 Photograph showing excavated area in the north yard on the west side of

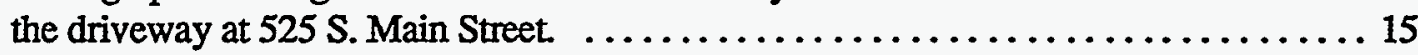

8 Photograph showing excavated areas in the south yard at 525 S. Main Street. ...... 16

9 Diagram showing layout and locations of smears taken in the den and the areas

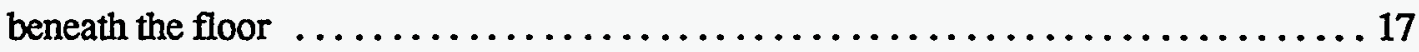

10 Diagram showing layout and locations of smears taken in the east bedroom area ..... 18

11 Diagram showing layout and locations of smears taken in the garage bathroom ..... 19

\section{LIST OF TABLES}

1 Applicable guidelines for protection against radiation $\ldots \ldots \ldots \ldots \ldots \ldots \ldots \ldots$

2 Background radiation levels for the Oxford, Ohio, area $\ldots \ldots \ldots \ldots \ldots \ldots \ldots$

3 Radionuclide concentrations in soil samples collected from the property at

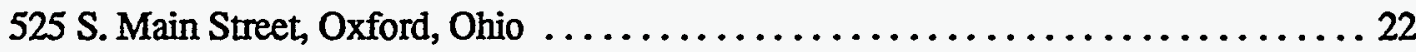

4 Results of gamma spectrometry analysis of smear samples collected from indoor surfaces in the residence at $525 \mathrm{~S}$. Main Street, Oxford, Ohio 23 
\begin{tabular}{|} 
\\
\\
\\
\\
\\
\end{tabular} 


\section{ACKNOWLEDGMENTS}

This project was sponsored by the Office of Environmental Restoration, U.S. Department of Energy, under contract DE-ACO5-960R22464 with Lockheed Martin Energy Research Corp. The authors wish to acknowledge the essential contributions of J. F. Allred, G. H. Cofer, R. C. Gosslee, R. A. Mathis, S. P. McKenzie, D. D. McKinney, V. P. Patania, R. E. Rodriguez, D. A. Roberts, D. A. Rose, P. F. Tiner, and W. Winton of the Measurement Applications and Development Group, Health Sciences Research Division, Oak Ridge National Laboratory, for their participation in collecting, reporting, and analyzing the data for this effort. The surveying assistance of A. C. Butler and the graphics skills of J. M. Lovegrove of Midwest Technical, Inc., are also gratefully acknowledged. 


\begin{abstract}
Between October 1952 and February 1957, National Lead of Ohio (NLO), a primary contractor for the Atomic Energy Commission (AEC), subcontracted certain uranium machining operations to Alba Craft Laboratory, Incorporated, located at 10-14 West Rose Avenue, Oxford, Ohio. In 1992, personnel from Oak Ridge National Laboratory (ORNL) confirmed the presence of residual radioactive materials from the AEC-related operations in and around the facility in amounts exceeding the applicable Department of Energy (DOE) guidelines. Above-guideline radiation levels were also found both indoors and outdoors at $525 \mathrm{~S}$. Main Street, a private residential property in the immediate vicinity of the Alba Craft site. This document reports the findings at this private residence.
\end{abstract}

Although the amount of uranium found on the properties posed little health hazard if left undisturbed, the levels were sufficient to require remediation to bring radiological conditions into compliance with current guidelines, thus ensuring that the public and the environment are protected. The Remedial Action Contractor for these properties was Bechtel National, Incorporated (BNI).

DOE requires that verification of completed cleanup work at DOE Formerly Utilized Sites Remedial Action Program (FUSRAP) sites such as this shall be performed and documented by an Independent Verification Contractor. The objective of verification activities is to certify that documentation of post-remedial action radiological conditions on the property is adequate, and the remedial action reduced contamination levels to within authorized limits.

A team from ORNL conducted a radiological verification survey of the property at $525 \mathrm{~S}$. Main Street, between November 1993 and December 1994. The survey was conducted at the request of DOE and included directly measured radiation levels, the collection and analysis of soil samples to determine concentrations of uranium and certain other radionuclides, and comparison of these data to the guidelines.

From a review of the post-remedial action report, it can be concluded that the BNI survey procedure used for this property was satisfactory. Furthermore, the results of the independent verification survey of the property at $525 \mathrm{~S}$. Main Street demonstrate that all contaminated areas have been remediated to radionuclide concentrations and activity levels below the applicable guideline limits set by DOE. 


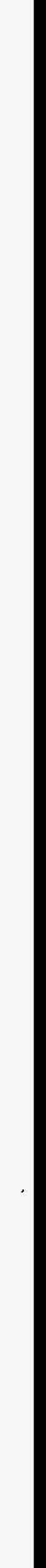




\section{Results of the Independent Radiological Verification Survey of the Remedial Action Performed at 525 South Main Street, Oxford, Ohio}

(OXO002)

\section{INTRODUCTION}

During the approximate time between October 1952 and February 1957, National Lead of Ohio (NLO), a primary contractor for the Atomic Energy Commission (AEC), subcontracted certain uranium machining operations to Alba Craft Laboratory, Incorporated, Oxford, Ohio. The facility, located at 10-14 West Rose Avenue, also housed operations involving NLO personnel and NLO uranium material in 1954. It is not known how much material was machined at the site by NLO in 1954, but the total quantity of uranium machined by Alba Craft is estimated at several hundred tons. Figure 1 shows the relative location of the City of Oxford in southwestern Ohio. Figure 2 is a diagram showing the approximate location of the former Alba Craft Laboratory site and $525 \mathrm{~S}$. Main Street in the City of Oxford.

Early investigations of the Alba Craft property had revealed evidence of residual radioactive materials from the AEC-related operations at the site. At the request of the Department of Energy (DOE) under the Formerly Utilized Sites Remedial Action Program (FUSRAP), personnel from Oak Ridge National Laboratory (ORNL) conducted a radiological assessment in 1992. The purpose of the survey was to locate and define the extent of the contamination on the site itself, and to detect whether any of these materials had migrated off-site. The results of that survey confirmed the early data suggesting that levels of radioactive residuals at the Alba Craft property were elevated above the applicable and appropriate DOE guidelines (Table 1) in and around the building. ${ }^{1}$ Radioactive residuals were also found both indoors and outdoors at the residential property at $\mathbf{5 2 5}$ South Main Street directly east of the site. Although the amount of uranium found posed little health hazard if left undisturbed, the levels were sufficient to require cleanup action to bring the property into compliance with current guidelines. The purpose of the process is to insure that the public and the environment are protected.

DOE's Environmental Restoration Program dictates that independent verification (IV) of completed cleanup work at DOE FUSRAP sites shall be performed and documented according to prescribed procedures prior to certification of the property for release for unrestricted use.2,3 The objective of verification activities is to confirm that the remedial action reduced contamination levels to within authorized limits.

As the designated IV Contractor (IVC) for this site, ORNL's Measurement Applications and Development Group was assigned to validate the remedial action and restoration activities conducted at this property by the Remedial Action Contractor, Bechtel National, Incorporated (BND). A verification survey of the property was performed during October and November, 1993, and in December and January, 1994.

"The survey was done by members of the Measurement Applications and Development Group, Health Sciences Research Division, Oak Ridge National Laboratory under DOE contract DE-AC05960R22464 with Lockheed Martin Energy Research Corp. 
The South Main Street residential property consisted of a two-story partial brick house with a concrete driveway and two concrete porches. Remedial action had been conducted inside the house and in outdoor areas at the north and south sides of the house. ${ }^{4}$ Figure 3 shows the layout of the property and the locations of remediated areas outdoors. The indoor remediation is not diagrammed in this report.

\section{SCOPE OF THE SURVEY}

The outdoor survey of the property included:

- A gamma scan near the ground surface over $100 \%$ of the property.

- Collection of systematic surface and subsurface soil samples.

- Collection of biased surface and subsurface soil samples.

- Measurements of gamma radiation levels at $1 \mathrm{~m}$ at soil sample locations .

- A thorough beta-gamma scan of excavated areas.

- On-site field screening using a portable gamma spectrometer to estimate uranium concentrations in soil samples.

The indoor survey of the property included:

- A gamma scan near the surface over accessible areas.

- A beta-gamma scan near the surface of accessible areas including overhead.

- Large area smears were collected and analyzed for removable alpha and beta-gamma activity levels.

\section{SURVEY METHODS}

Descriptions of typical survey methods and instrumentation providing guidance for this survey are given in Procedures Manual for the ORNL Radiological Survey Activities (RASA) Program, ORNL/TM-8600 (April 1987), and in Measurement Applications and Development Group Guidelines, ORNL-6782 (January 1995).5,6

\section{SURFACE RADIATION MEASUREMENTS}

Indoors, open floor areas were scanned using a Ludlum 2221 meter with a Ludlum 23-1F floor monitor. Space-restricted and elevated areas were then measured using portable gamma and beta-gamma instrumentation. Gamma radiation levels were determined using a portable NaI gamma scintillation meter. Because NaI gamma scintillators are energy dependent, measurements of gamma radiation levels in counts per minute (cpm) are normalized to pressurized ionization chamber (PIC) measurements to estimate gamma exposure rates in $\mu \mathrm{R} / \mathrm{h}$. Using a Geiger-Mueller pancake detector, beta-gamma radiation levels were measured in counts per minute (cpm) near contact with accessible hard surfaces. The cpm were then converted to millirad per hour (mrad/h) and disintegrations per minute over $100 \mathrm{~cm}^{2}\left(\mathrm{dpm} / 100 \mathrm{~cm}^{2}\right)$ for comparison with guideline 
values. Gamma exposure rate readings of more than $16 \mu \mathrm{R} / \mathrm{h}$ and/or a direct beta-gamma activity level or dose rate of more than $3,000 \mathrm{dpm} / 100 \mathrm{~cm}^{2}$ or $0.05 \mathrm{mrad} / \mathrm{h}$, respectively, triggered a need for further evaluation. Random spot-checks using an ORNL alpha survey meter connected to a zinc sulfide scintillation probe were done to detect directly measured alpha activity levels in open indoor areas.

\section{SAMPLING AND ANALYSES}

Systematic surface $(0-$ to $15-\mathrm{cm})$ soil samples were collected outdoors in all remediated areas at selected locations without regard to radiation levels (e.g., at grid points). Systematic soil samples were also taken at locations surrounding anomalies to define the boundaries of any contamination, and repeatedly at locations where remediation was incomplete. Biased samples were collected at locations of anomalous beta-gamma radiation levels. Where appropriate, subsurface soil samples were taken at these locations at increments of $15 \mathrm{~cm}$ below the surface.

During the December and January activities, a new screening device was used to provide an estimate of uranium content ( $\mathrm{pCi} / \mathrm{g}$ ) in the field. The procedure consisted of on-site analyses of freshly collected soil samples using a portable gamma spectrometer. The results of the analyses were then used along with the beta-gamma measurements to make an immediate assessment. The reliability of the field screening method was established at another site by comparison of the field-estimated uranium concentration in a specific sample to the results found from later laboratory analysis of that same sample. When the comparisons proved to be dependable, the field screening method was relied upon to provide the basis for an immediate decision on further remedial action. The assessment, remediation, and verification processes were thereby considerably expedited. Furthermore, the approach was conservative in that the maximum uranium concentration resulting from multiple field analyses done on a single sample was selected for comparison with the derived site-specific $238 \mathrm{U}$ guideline $(17.5 \mathrm{pCi} / \mathrm{g}$, Table 1$)$. The process of drying, weighing, grinding, and homogenizing samples according to the required QA procedures was done in the laboratory later as confirmation of radionuclide concentrations. This report details both field and laboratory analysis results for samples collected by ORNL in successfully remediated locations. In addition, selected samples collected and analyzed earlier by BNI were later split and re-analyzed by ORNL for verification of results.

Selected indoor areas were assessed for possible removable alpha and beta-gamma activity levels by wiping surfaces with cloths (smears) that were subjected to gross counting at the site and later laboratory spectrometry analysis.

\section{SURVEY RESULTS}

Current DOE guidelines for sites included within FUSRAP are summarized in Table 1; the derived site-specific guideline for 238U is also listed.7 Typical background radiation levels for the Oxford, Ohio, area are presented in Table 2. These data are provided for comparison with the 
survey results presented in this report. Gamma radiation levels are reported in gross $\mu \mathrm{R} / \mathrm{h}$. Background concentrations have not been subtracted from radionuclide concentrations in soil, debris, or other materials.

The verification survey at this property was initiated by ORNL on October 25,1993 , immediately following BNI's notification that some indoor areas had been cleaned sufficiently to satisfy the guidelines (Table 1). All subsequent verification was done sporadically inside and outside the residence in response to BNI's activities in those locations.

\section{OUTDOOR RESULTS}

On December 5, 1994, BNI notified ORNL that the outdoor remedial activities at 525 S. Main Street had been completed. Two separate grid systems were established on the property to allow the precise location of measurements and samples (Figs. 4 and 5). ORNL then surveyed the five excavated locations comprising one large area and two small areas south of the house, and two smaller areas north of the house (Fig. 3). A gamma walkover survey and a thorough beta-gamma scan of these areas were conducted. Table 3 details analytical results for concentrations of $238 \mathrm{U}$ in soil samples collected from this property following remediation of all areas.

\section{North Yard}

Beta-gamma scanning over the two excavated areas in the north yard (Fig. 4) revealed several anomalies (i.e., beta activity at $>3,000 \mathrm{dpm} / \mathrm{cm}^{2}$ ) on both sides of the driveway although gamma exposure rates were no more than $8 \mu \mathrm{R} / \mathrm{h}$. The areas were re-sampled at nine systematic locations (VS1 to VS9) and seven biased locations. Field screening of the systematic samples showed $238 \mathrm{U}$ concentrations ranging from less than background to $12 \mathrm{pCi} / \mathrm{g}$ (Table 3). Field screening for five of the biased samples showed values exceeding the $238 \mathrm{U}$ soil contamination guidelines for Oxford with a maximum concentration of $79 \mathrm{pCi} / \mathrm{g}$. ORNL requested that BNI conduct further remediation in these areas. Photographs showing views of the excavated areas in progress are shown on Figs. 6 and 7.

ORNL repeated the beta-gamma scanning on December 8 following re-excavation of those areas of the north yard. Several anomalies were again found on both sides of the driveway. Field screening of samples VB1 through VB10 taken from the east side of the driveway showed concentrations of $238 \mathrm{U}$ ranging from 2 to $17 \mathrm{pCi} / \mathrm{g}$ (Table 3), values less than the guideline (Table 1). That area was released to BNI for final restoration. Field screening indicated concentrations of $238 \mathrm{U}$ ranging from 31 to $140 \mathrm{pCi} / \mathrm{g}$ in three samples from the area on the west side of the driveway. Additional cleanup of that area was requested and performed.

On December 15, ORNL performed another beta-gamma scan of the area on the west side of the driveway with the result that more anomalies were found. Biased samples again collected from the re-excavated area were shown by field screening to contain concentrations of $238 \mathrm{U}$ exceeding the limit (to a maximum of $70 \mathrm{pCi} / \mathrm{g}$ ). 
Following a third excavation of the west side of the driveway on December 16, beta-gamma scanning revealed additional anomalous areas indicating that radioactive residuals still remained. The anomalies (to $63 \mathrm{pCi} / \mathrm{g} 238 \mathrm{U}$ ) were confirmed by field screening of additional soil samples.

A fourth attempt by BNI to remove all contamination west of the driveway was followed by an ORNL beta-gamma scan on December 28. Several more anomalies were found, and soil samples were again collected. Field screening of newly collected soil samples VB21 and VB22 indicated $238 \mathrm{U}$ at concentrations of 9.2 and $14 \mathrm{pCi} / \mathrm{g}$, respectively. Because these values are less than the maximum derived guideline of $17.5 \mathrm{pCi} / \mathrm{g}$ (Table 1), the area was released to BNI for complete restoration of the property.

\section{South Yard}

The three excavated areas in the yard south of the house showed no anomalies during the scans. Gamma exposure rates ranged from 3 to $8 \mu \mathrm{R} / \mathrm{h}$ and beta-gamma measurements were $<3,000 \mathrm{dpm} / 100 \mathrm{~cm}^{2}$. Because the results were comparable to typical background and less than DOE guidelines, no biased samples were collected. Systematic samples (VS10 through VS14) were collected at five locations from the three excavated areas in the south yard (Fig. 8). Field screening of these samples showed $238 \mathrm{U}$ concentrations ranging from less than background to $4.9 \mathrm{pCi} / \mathrm{g}$, well below the site-specific soil contamination guideline of $17.5 \mathrm{pCi} / \mathrm{g}$ derived for the Oxford, Ohio sites (Table 1). ORNL then released the remediated south yard areas to BNI for restoration. Final analytical results in soil samples from those areas are shown in Table 3.

\section{INDOOR RESULTS}

Areas remediated inside the house included the den, its sub-floor and the crawlspace beneath it, an upstairs bedroom and its sub-floor, and the bathroom in the garage. At various times during remediation and verification, the original hardwood floors in the den and in the bedroom above the garage had been removed by either BNI or a private flooring contractor hired by the owner. ORNL also requested that BNI remove some parts of cabinets and shelves throughout the dwelling (living areas, etc.) to allow access to areas beneath and behind the structures. All measured areas showed results less than guidelines (Table 1). The following discussion of activities is arranged according to room or area.

\section{Den, Sub-floor, and Crawlspace}

October 25, 1993, the ORNL team found elevated beta-gamma activity levels in the den following removal of the tarpaper that had underlain the hardwood flooring. Anomalous areas ranged from 3,000 to $12,000 \mathrm{dpm} / 100 \mathrm{~cm}^{2}(0.05$ to $0.2 \mathrm{mrad} / \mathrm{h})$. Two spots were remediated with tape. Additional BNI remediation lowered all previously ORNL-identified anomalies in this area of the den to acceptable levels (Table 1). A $100 \%$ walkover scan with gamma scintillators 
revealed exposure rates ranging from 6 to $10 \mu \mathrm{R} / \mathrm{h}$, values well below the guideline of $20 \mu \mathrm{R} / \mathrm{h}$ above background (Table 1). Spot-checking with alpha scintillators showed activity levels of 7.2-29 dpm/100 $\mathrm{cm}^{2}$. Results of analysis of five smear samples (VT7 - VT11, Fig. 9) were all less than minimum detectable activity (MDA, Table 4).*

On January 6, 1994, ORNL conducted verification activities as BNI remediated the crawl space beneath the den. After BNI removed a section of the sub-floor and a few floor joists, TMA/Eberline** and ORNL surveyed the joists and the fireplace hearth facing. In general, the fireplace hearth facing had beta-gamma activity levels ranging from 1,100 to $3,000 \mathrm{dpm} / 100 \mathrm{~cm}^{2}$ ( 0.02 to $0.05 \mathrm{mrad} / \mathrm{h})$. A particle or shaving (apparently uranium) had beta-gamma activity levels of $60,000 \mathrm{dpm} / 100 \mathrm{~cm}^{2}(1 \mathrm{mrad} / \mathrm{h})$. Anomalous beta-gamma activity levels in other locations in the crawl space ranged from 5,400 to $60,000 \mathrm{dpm} / 100 \mathrm{~cm}^{2}(0.09$ to $1 \mathrm{mrad} / \mathrm{h})$. The elevated spots were remediated by BNI and ORNL. ORNL re-surveyed the area and collected additional smears showing analytical results of all to be less than MDA.

The following day, ORNL personnel surveyed the dirt floor and the wooden floor supports in the crawl space beneath the den. Approximately 10 elevated spots were found between the fireplace hearth and the raised dirt area in the crawl space. Soil readings were $>3,000 \mathrm{dpm}$ $/ 100 \mathrm{~cm}^{2}$ beta-gamma; spots over the horizontal surfaces of the fireplace footer ranged from 4,500 to $90,000 \mathrm{dpm} / 100 \mathrm{~cm}^{2}(0.08$ to $1.5 \mathrm{mrad} / \mathrm{h})$. ORNL surveyed approximately $45 \mathrm{ft}^{2}$ of soil in this area, including characterizing, remediating, and verifying activities. A beta-gamma anomaly reading $10,000 \mathrm{dpm} / 100 \mathrm{~cm}^{2}(0.18 \mathrm{mrad} / \mathrm{h})$ was found approximately seven feet west of the center of the hearth. This spot was remediated and verified by ORNL. A beta-gamma anomaly measuring $19,000 \mathrm{dpm} / 100 \mathrm{~cm}^{2}(0.32 \mathrm{mrad} / \mathrm{h})$ was found on the bottom of the south baseboard. This area was also remediated and verified by ORNL. All surfaces of the three floor joists west of the fireplace hearth were surveyed with the result that two beta-gamma anomalies measuring 5,400 and $6,900 \mathrm{dpm} / 100 \mathrm{~cm}^{2}(0.09$ and $0.12 \mathrm{mrad} / \mathrm{h})$ were found. These were then remediated by BNI and verified by ORNL. After remediation, beta-gamma activity levels on all surfaces of the joists ranged from 1,000 to $1,700 \mathrm{dpm} / 100 \mathrm{~cm}^{2}(0.02$ to $0.03 \mathrm{mrad} / \mathrm{h})$. An additional $100 \mathrm{ft}^{2}$ of soil west of the raised soil area was also surveyed by ORNL. The background beta-gamma of the soil areas ranged from 1,800 to $2,700 \mathrm{dpm} / 100 \mathrm{~cm}^{2}$. Approximately $0.044 \mathrm{~m}^{3}$ of soil were removed from the crawl space during ORNL's remediation activities. Collected soil and remediation debris collected by ORNL was tumed over to BNI for proper disposal.

On January 8, 1994, ORNL continued surveying the crawl space under the den. Generally, beta-gamma activity levels in the crawl space ranged from 2,000 to $3,300 \mathrm{dpm} / 100 \mathrm{~cm}^{2}(0.03$ to $0.05 \mathrm{mrad} / \mathrm{h}$ ); gamma exposure rates ranged from 6 to $10 \mu \mathrm{R} / \mathrm{h}$. However, additional anomalies $\left(>3,000 \mathrm{dpm} / 100 \mathrm{~cm}^{2}\right.$ beta-gamma) were again identified in the soil and on wood on top of the foundation underneath the door leading from the den to the south porch. The beta-gamma activity levels on the wood were 6,000 to $12,000 \mathrm{dpm} / 100 \mathrm{~cm}^{2}(0.1$ to $0.2 \mathrm{mrad} / \mathrm{h})$. Beta-gamma activity

\footnotetext{
*The instrument-specific minimum detectable activities (MDAs) for removable alpha and beta-gamma radiation levels are 10 and $200 \mathrm{dpm} / 100 \mathrm{~cm}^{2}$, respectively.

*TMA/Eberline is another DOE subcontractor assigned to the property.
} 
levels over the soil surface underneath the door leading to the garage from the den were $>3,000 \mathrm{dpm} / 100 \mathrm{~cm}^{2}$. Alpha activity levels in the crawl space ranged from 72 to $338 \mathrm{dpm}$ $/ 100 \mathrm{~cm}^{2}$. Alpha measurements at these slightly higher-than-normal levels generally result from emanation of radon produced from natural radioactivity in the soil. The alpha activity accumulates in areas such as crawlspaces and basements because it cannot dissipate as rapidly as it might in adequately ventilated areas. The levels are well below guidelines (Table 1). Three biased soil samples and four systematic soil samples were taken from the crawl space. BNI decided that these areas would be remediated at a later date.

On March 7, 1994, ORNL resumed verification activities in the crawl space under the den. An anomaly ranging from 6,000 to $21,000 \mathrm{dpm} / 100 \mathrm{~cm}^{2}(0.1$ to $0.36 \mathrm{mrad} / \mathrm{h})$ was brought to the attention of BNI and was subsequently remediated.

\section{East Bedroom Area}

Elevated areas found on the east bedroom floor above the garage ranged from 4,500 to $37,000 \mathrm{dpm} / 100 \mathrm{~cm}^{2}(0.08$ to $0.61 \mathrm{mrad} / \mathrm{h})$ beta-gamma. Some removal of the sub-floor was required to remediate all areas to $<3,000 \mathrm{dpm} / 100 \mathrm{~cm}^{2}$ beta-gamma. A $100 \%$ scan with gamma scintillators disclosed exposure rates of 6 to $8 \mu \mathrm{R} / \mathrm{h}$, values well below the guideline of $20 \mu \mathrm{R} / \mathrm{h}$ above background (Table 1). Spot-checking showed alpha activity levels of less than MDA to $22 \mathrm{dpm} / 100 \mathrm{~cm}^{2}$. Four smear samples (VT12 - VT15) were taken from the locations as shown on Fig. 10. The values were less than MDA.

Elevated gamma measurements in an upstairs closet next to the east bedroom led to the discovery of a luminous toggle switch containing radium. The device was concealed behind a wall near the chimney. It was removed and packaged as sample $M 3$. No analysis was performed. The general area showed measurements of 900 to $1,500 \mathrm{dpm} / 100 \mathrm{~cm}^{2}$ beta-gamma with no anomalies.

\section{Garage Bathroom}

On October 27, 1993, IVC surveying of the bathroom in the garage disclosed areas of elevated beta-gamma activity ranging from 6,000 to $225,000 \mathrm{dpm} / 100 \mathrm{~cm}^{2}(0.1$ to $3.4 \mathrm{mrad} / \mathrm{h})$ in eleven unremediated locations. Approximately $50 \%$ of the hidden wooden shelf behind the commode ranged from 3,000 to $30,000 \mathrm{dpm} / 100 \mathrm{~cm}^{2}(0.05$ to $0.65 \mathrm{mrad} / \mathrm{h})$ requiring supplementary BNI remediation. Measurements on the floor areas underneath the shelf and the stairs revealed no anomalies.

Later that afternoon, ORNL repeated the verification survey of the garage bathroom after supplemental BNI remediation. Seven new beta-gamma anomalies were identified, ranging from 4,500 to $15,000 \mathrm{dpm} / 100 \mathrm{~cm}^{2}(0.08-0.25 \mathrm{mrad} / \mathrm{h})$. A debris sample was collected from the shower drain (Fig. 11). Laboratory analysis later showed that the sample contained $280 \mathrm{pCi} / \mathrm{g}$ 238U. ORNL notified BNI that additional remediation of the bathroom floor was required. Remedial action was followed by a $100 \%$ scan showing gamma exposure rates ranging from 9 to $12 \mu \mathrm{R} / \mathrm{h}$, and total (fixed and removable) alpha measurements ranging from 29 to $94 \mathrm{dpm}$ $1100 \mathrm{~cm}^{2}$. Three smear samples were taken from the floor in the locations shown on Fig. 11 (T16, T17,T18). Results showed values of less than MDA for both alpha and beta-gamma measurements. All results are below DOE guidelines (Table 1). 
ORNL again surveyed the garage bathroom on the day following more BNI remediation in that room. Four anomalies $\left(>3,000 \mathrm{dpm} / 100 \mathrm{~cm}^{2}\right.$ beta-gamma) remained on the bathroom floor. It was decided mutually by ORNL and BNI to delay further remediation and verification of the bathroom floor until later on in the cleanup process.

On March 9, 1994, ORNL confirmed that the remediation in the garage and the bathroom above it was sufficient to meet the guidelines. The floors generally had beta-gamma activity levels ranging from 1,500 to $2,700 \mathrm{dpm} / 100 \mathrm{~cm}^{2}(0.02$ to $0.04 \mathrm{mrad} / \mathrm{h})$, and overhead measurements ranging from 1,200 to $2,200 \mathrm{dpm} / 100 \mathrm{~cm}^{2}(0.02$ to $0.04 \mathrm{mrad} / \mathrm{h})$.

Instrumentation interference from a large collection of assorted metallic materials inside the garage prevented tracing the bathroom shower drain to its terminus. Therefore, that drain as well as two other drains inside the garage were permanently sealed by ORNL to prevent possible access to or redistribution of any contaminants.

\section{INDOOR RESULTS SUMMARY}

Final indoor verification was conducted March 9, 1994 by BNI and TMA Eberline with oversight by ORNL. A beta-gamma scan of $100 \%$ of accessible floor surfaces was performed. ORNL also made measurements in every third grid block and spot-checked all overhead locations. Floors typically measured 1,500 to $2,700 \mathrm{dpm} / 100 \mathrm{~cm}^{2}(0.02$ to $0.04 \mathrm{mrad} / \mathrm{h}) ;$ overhead areas typically measured 1,200 to $2,200 \mathrm{dpm} / 100 \mathrm{~cm}^{2}(0.02$ to $0.04 \mathrm{mrad} / \mathrm{h})$. Measurements in the garage including the area of the former stairway and bathroom were generally $1,800 \mathrm{dpm}$ $1100 \mathrm{~cm}^{2}(0.03 \mathrm{mrad} / \mathrm{h})$. A few locations in the bathroom area measured $1,200 \mathrm{dpm} / 100 \mathrm{~cm}^{2}$. Although the area under the gas furnace could not be $100 \%$ verified, accessible areas were no higher than $3,600 \mathrm{dpm} / 100 \mathrm{~cm}^{2}(0.06 \mathrm{mrad} / \mathrm{h})$. Beta-gamma levels were $-3,000 \mathrm{dpm} / 100 \mathrm{~cm}^{2}$ $(0.05 \mathrm{mrad} / \mathrm{h})$ in the main drain in the garage after remediation (before sealing).

\section{SIGNIFICANCE OF FINDINGS}

From a review of the post-remedial action report, it can be concluded that the BNI survey objectives for this property were achieved. Furthermore, the results of the independent verification survey of the property at $525 \mathrm{~S}$. Main Street demonstrate that all contaminated areas have been remediated to radionuclide concentrations and activity levels below the applicable guideline limits set by DOE. 


\section{REFERENCES}

1. M. E. Murray, K. S. Brown, and R. A. Mathis, Results of the Radiological Survey at the Former Alba Craft Laboratory Site Properties, Oxford, Ohio (OXO001), ORNL/RASA92/14, Martin Marietta Energy Systems, Oak Ridge Natl. Lab., March 1993.

2. R. P. Whitfield, Deputy Assistant Secretary for Environmental Restoration, U.S. DOE, memorandum to J. J. Fiore, Director, Office of Eastern Area Programs, Office of Environmental Restoration, U.S. DOE, May 6, 1992.

3. Verification and Certification Protocol--Supplement No. 2 to the FUSRAP Summary Protocol, Rev. 1, U.S. DOE, Office of Nuclear Energy, Division of Facility and Site Decommissioning Projects, November 1985.

4. Post-Remedial Action Report for the Alba Craft Site and Vicinity Properties, DOE/OR 121949, Bechtel National, Inc., Oak Ridge, Tennessee, January 1995.

5. Procedures Manual for the ORNL Radiological Survey Activities (RASA) Program, ORNL/TM-8600, Martin Marietta Energy Systems, Inc., Oak Ridge Natl. Lab., April 1987.

6. Measurement Applications and Development Group Guidelines,ORNL-6782, Martin Marietta Energy Systems, Oak Ridge, Natl. Lab., January 1995.

7. W. A. Williams, Designation and Certification Manager, Division of Off-Site Programs, Office of Eastem Area Programs, Office of Environmental Restoration, U.S. Department of Energy, memorandum, "Uranium Guidelines for the Alba Craft Site, Oxford, Ohio," to L. K. Price, Director, Former Sites Restoration Division, Oak Ridge Field Office, U.S. Department of Energy. 
ORNL-DWG 92-9817

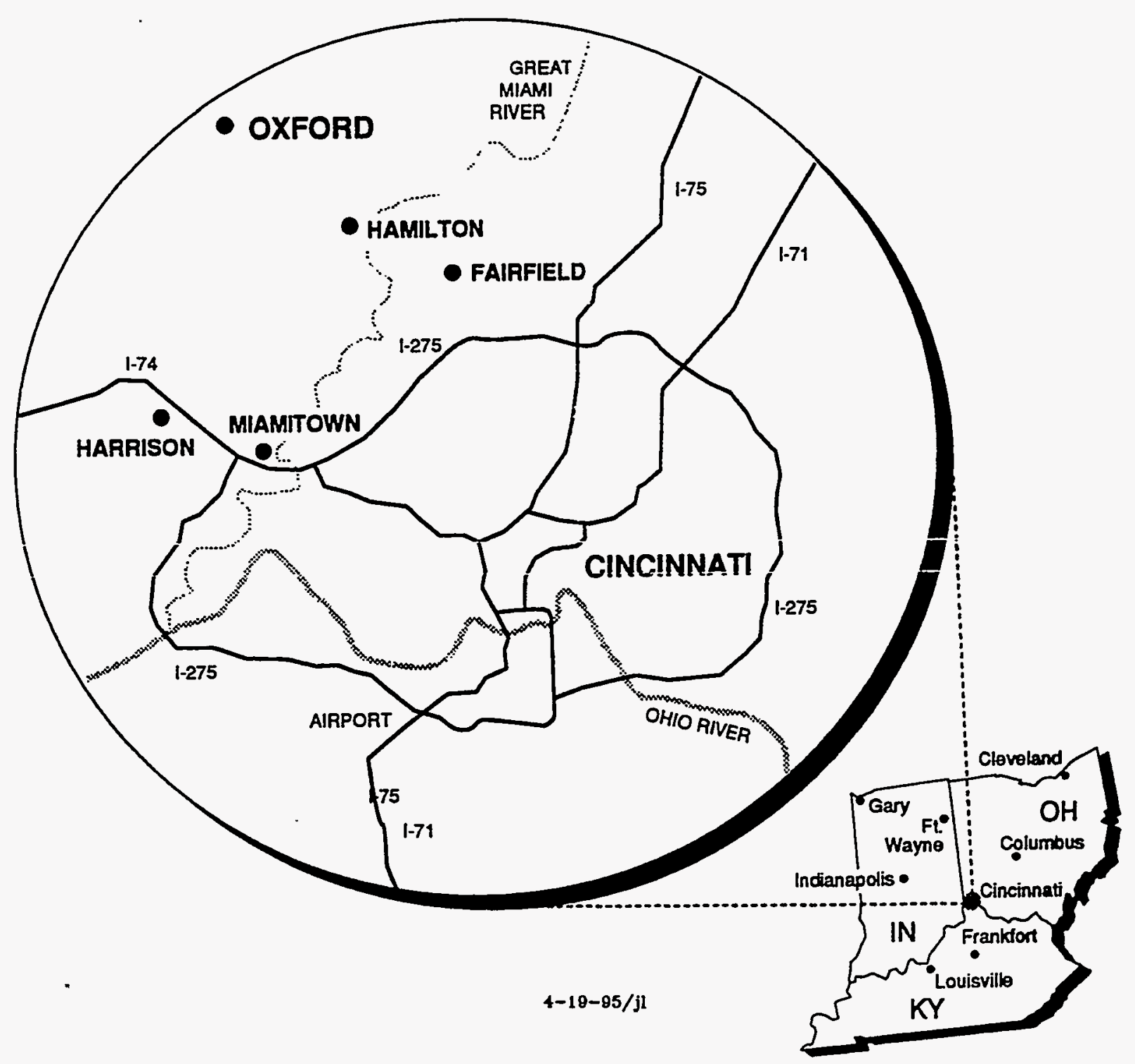

Fig. 1. Diagram showing the general location of Oxford, Ohio. 


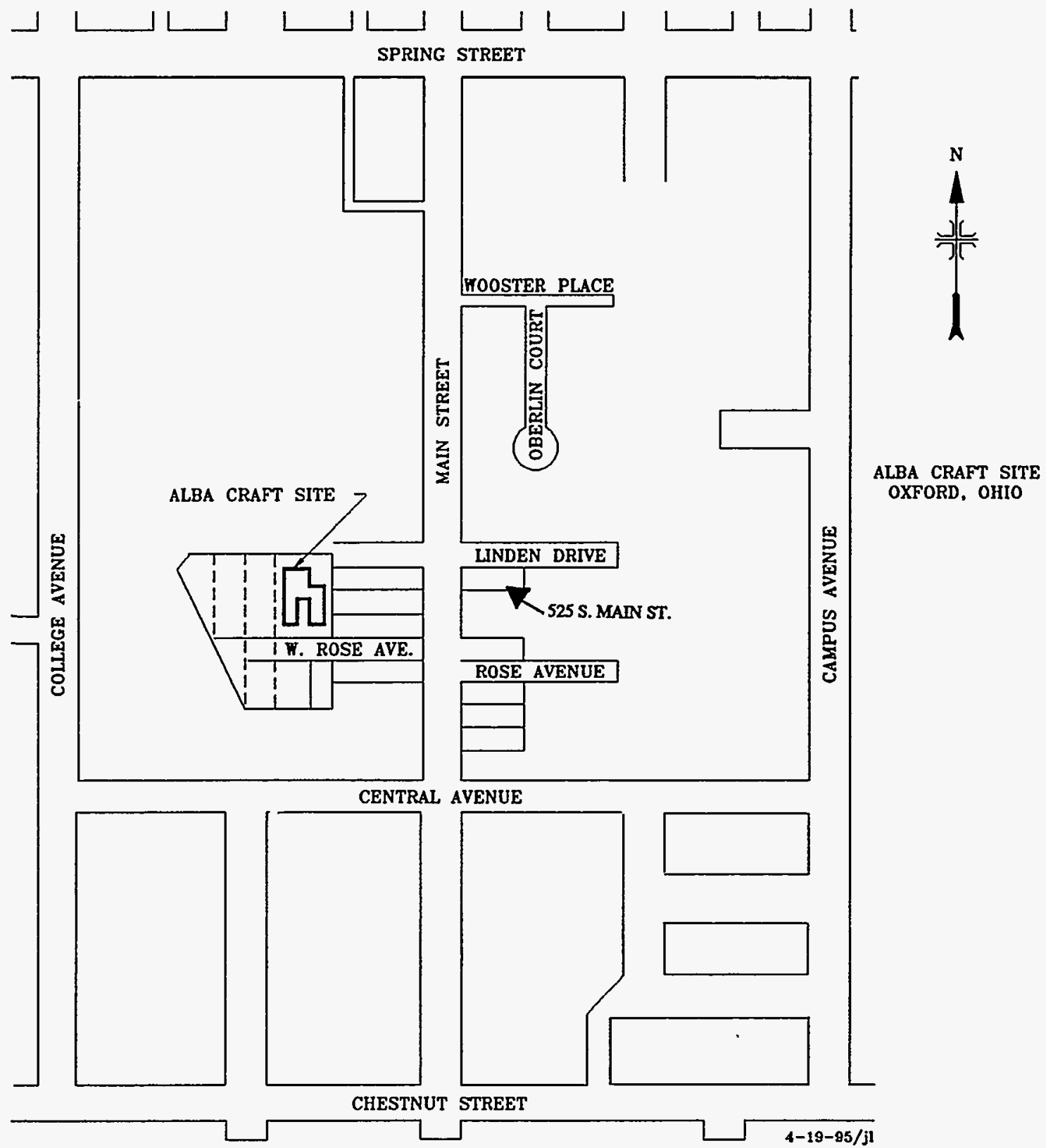

Fig. 2. Diagram showing the general location of the former Alba Craft Laboratory site and 525 S. Main Street, Oxford, Ohio. 


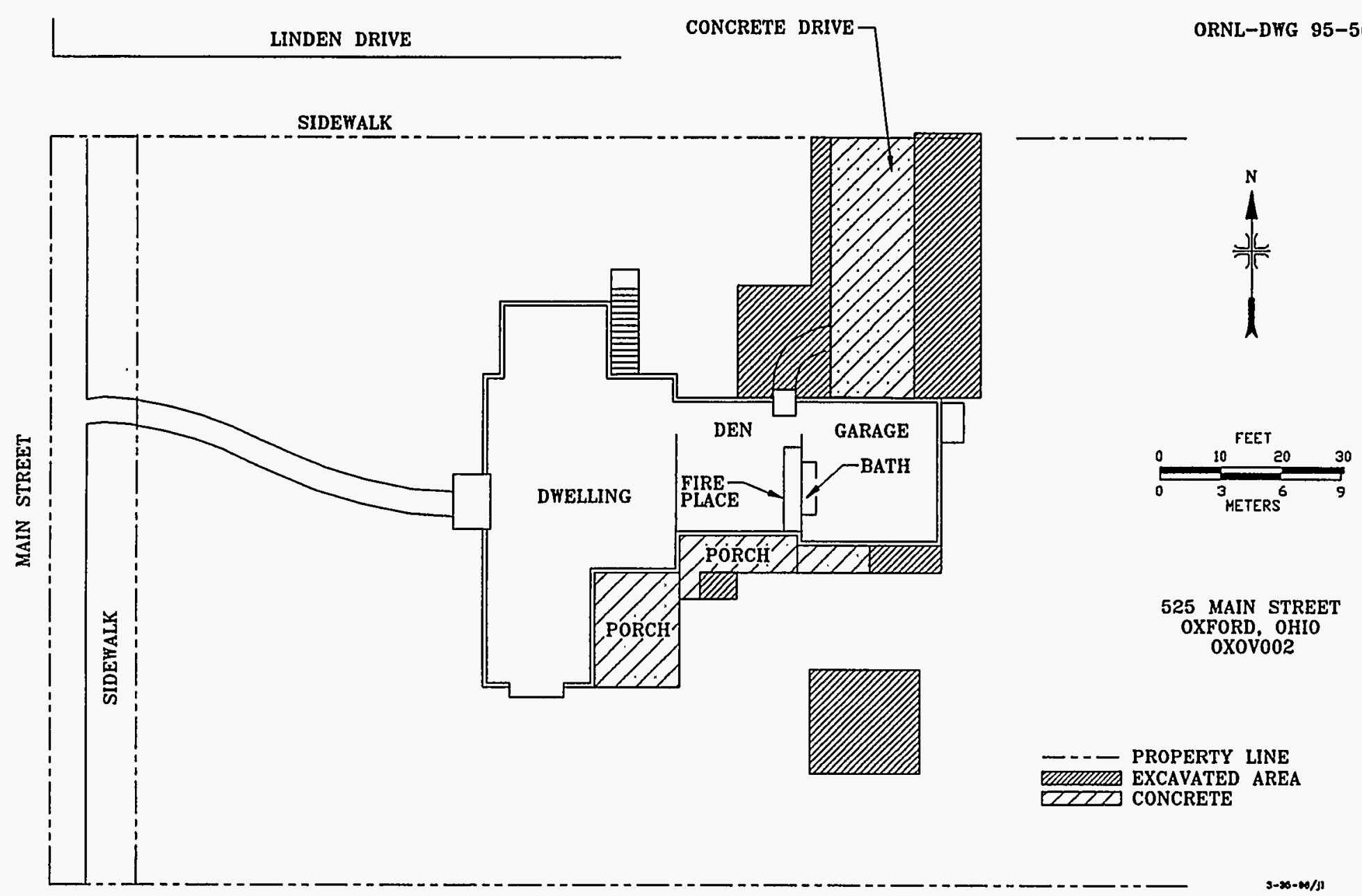

Fig. 3. Diagram showing the layout of the residential property at $525 \mathrm{~S}$. Main Street and the excavated areas. 


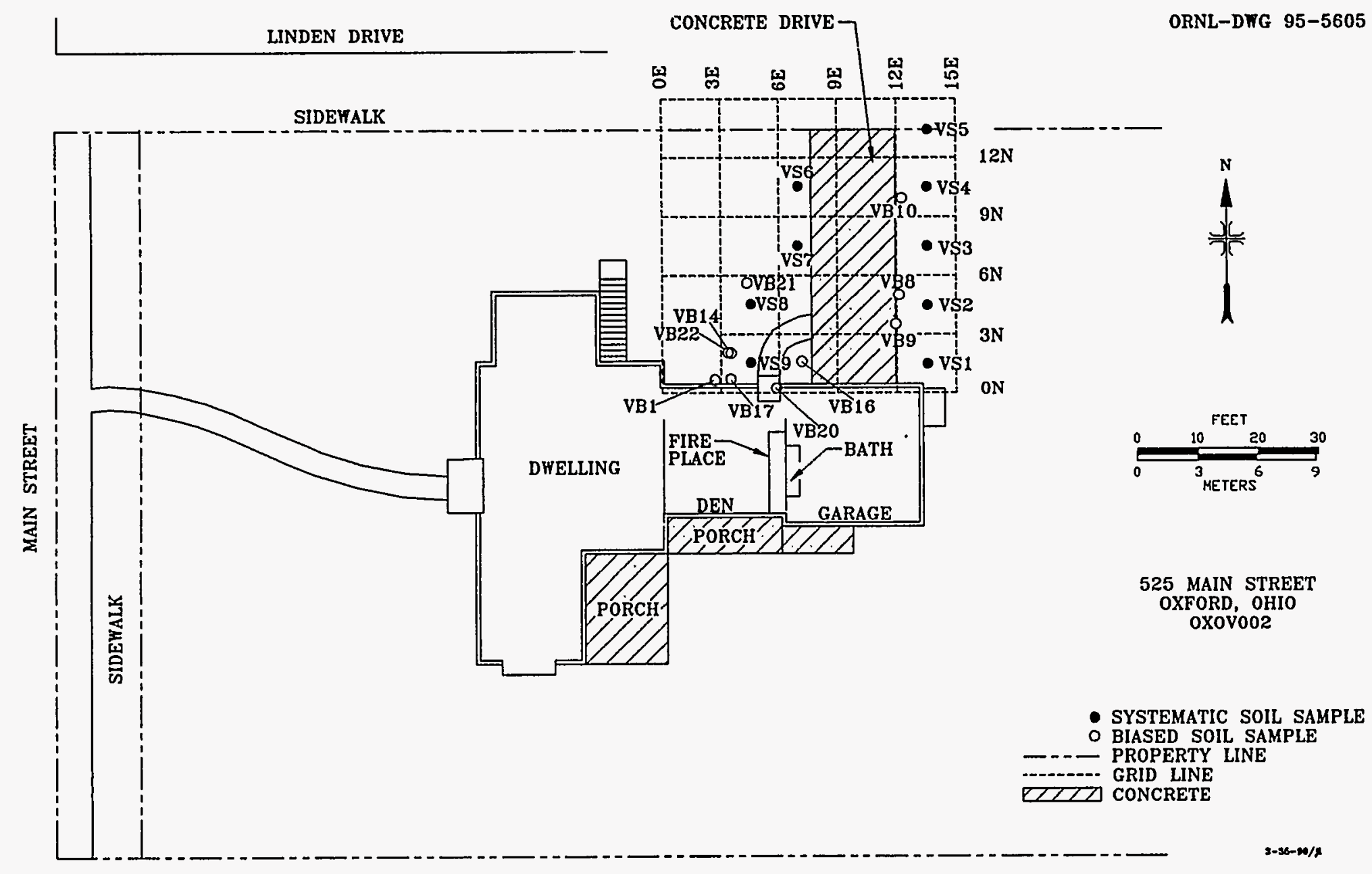

Fig. 4. Diagram showing grid and locations of soil samples collected from the North Yard at $525 \mathrm{~S}$. Main Street. 


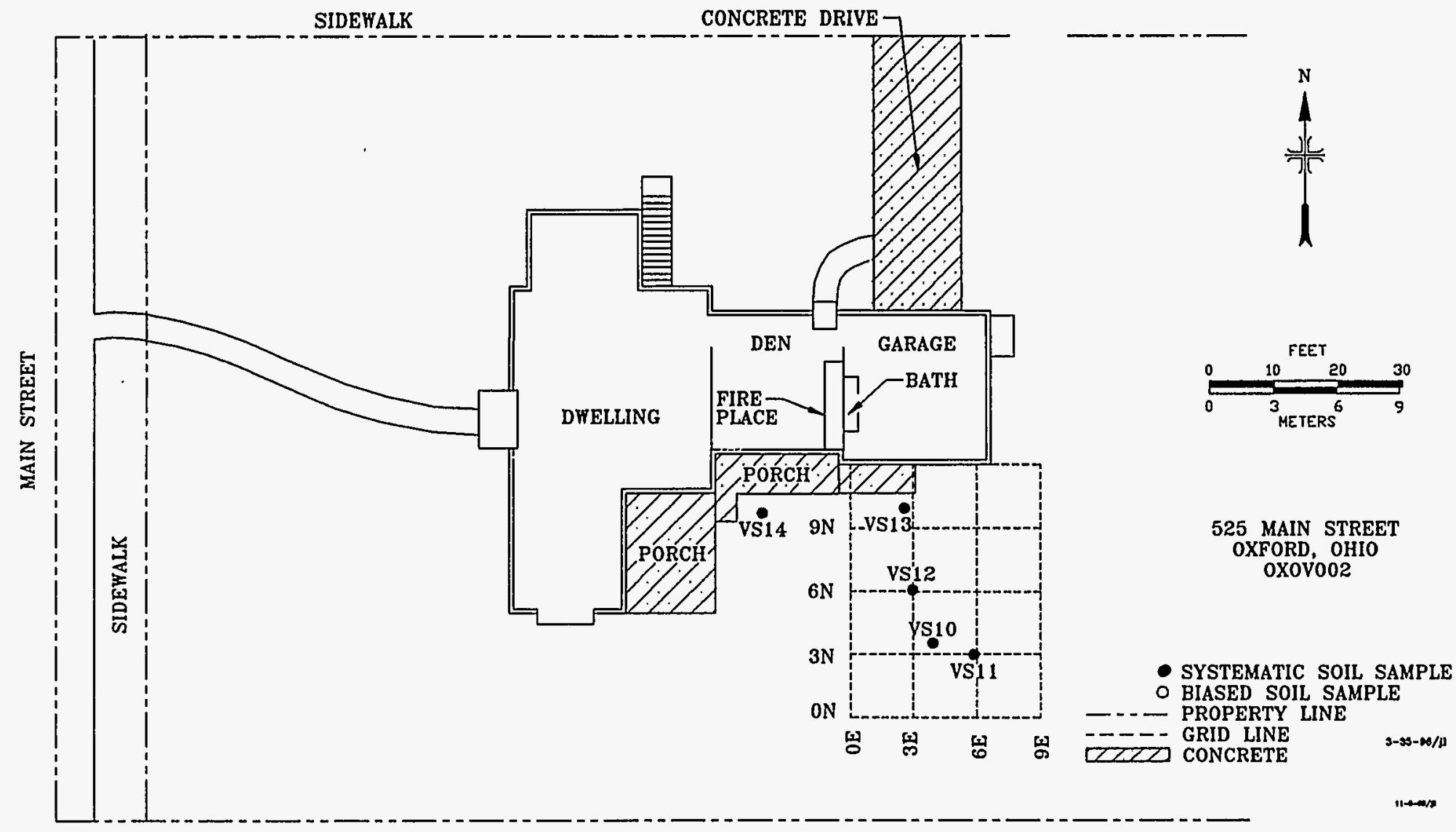

Fig. 5. Diagram showing grid and locations of soil samples collected from the South Yard at 525 S. Main Street. 
ORNL-PHOTO $9879-95$

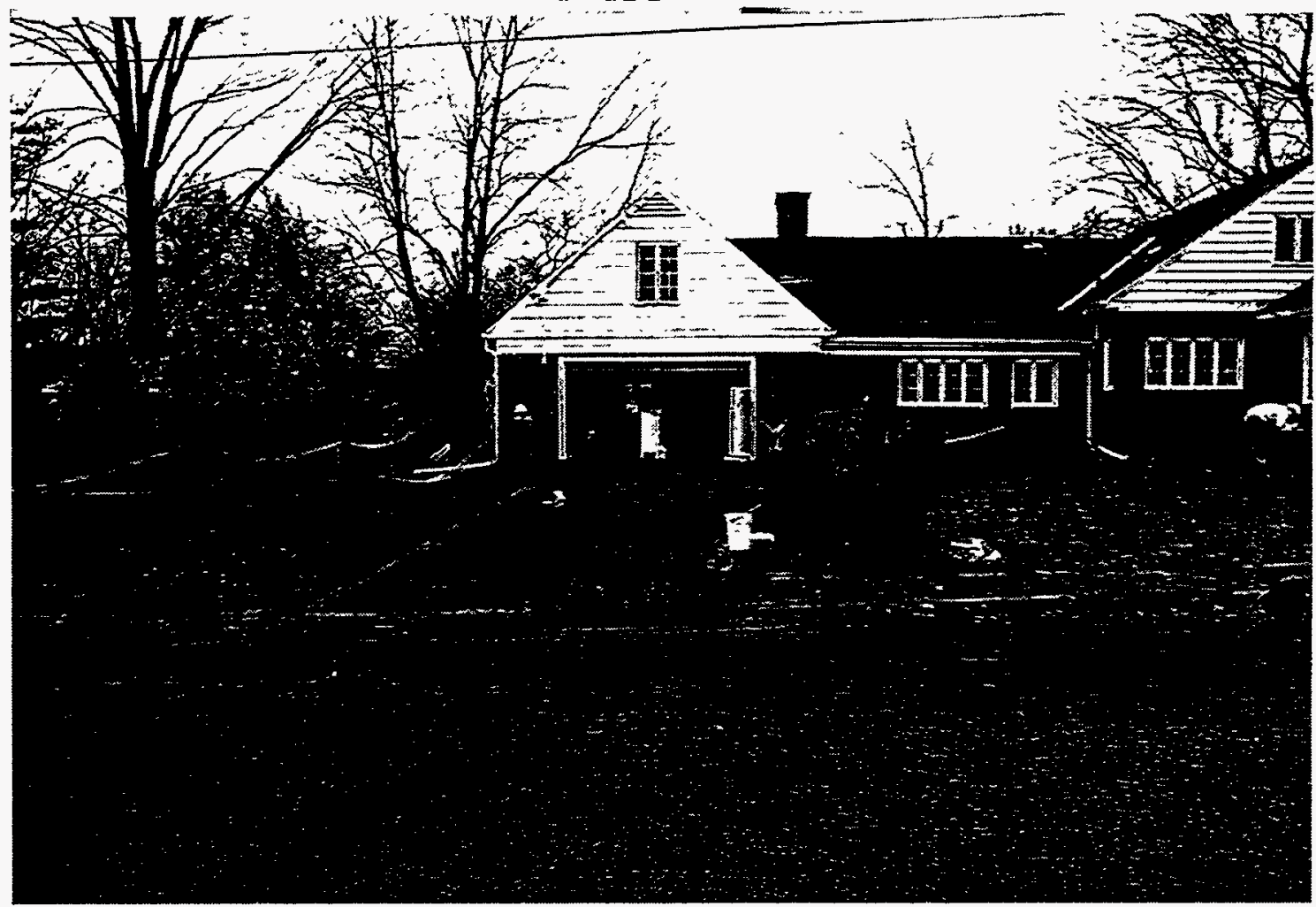

Fig. 6. Photograph showing excavated areas in the north yard on each side of the driveway at 525 S. Main Street.

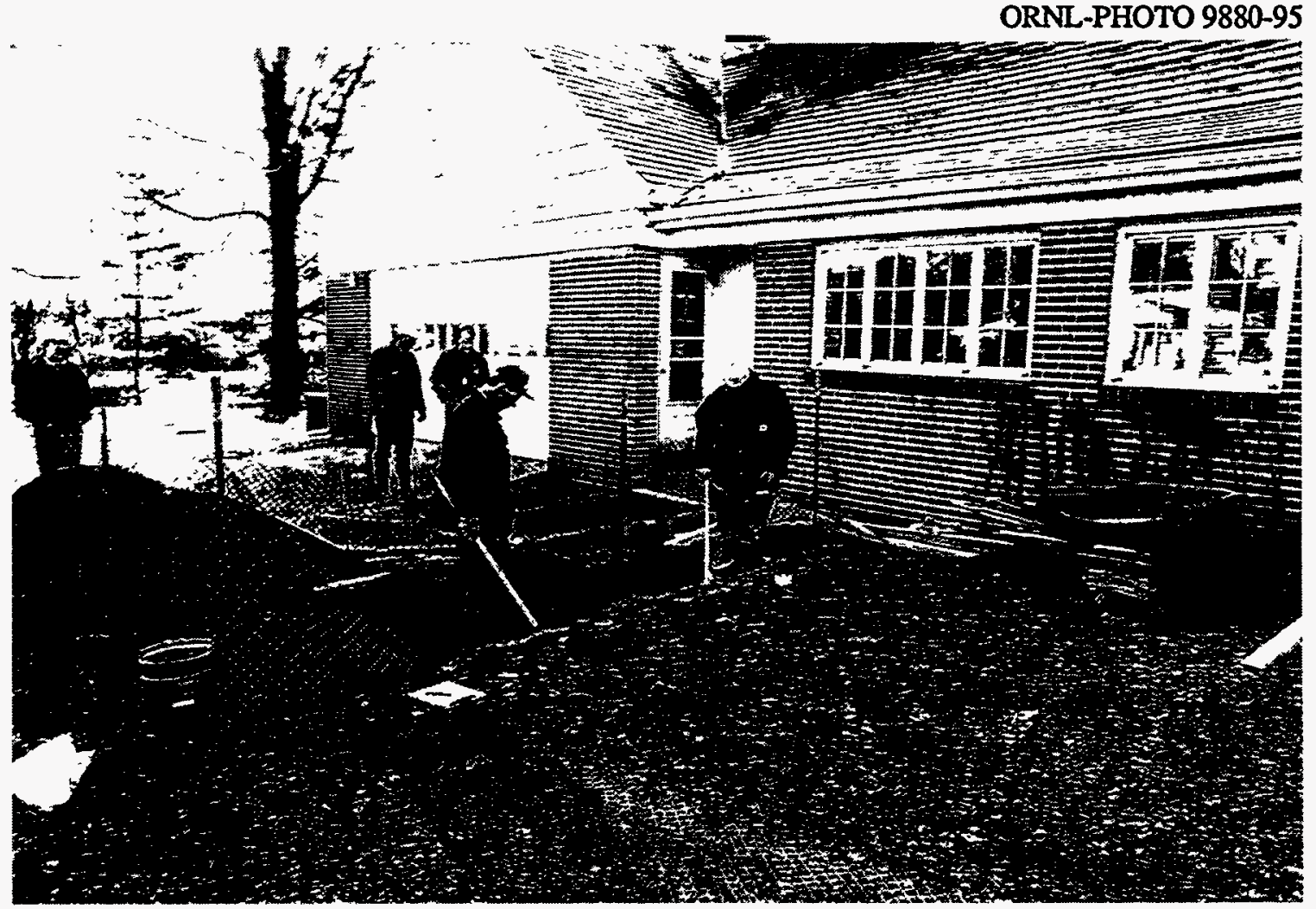

Fig. 7. Photograph showing excavated area in the north yard on the west side of the driveway at 525 S. Main Street. 


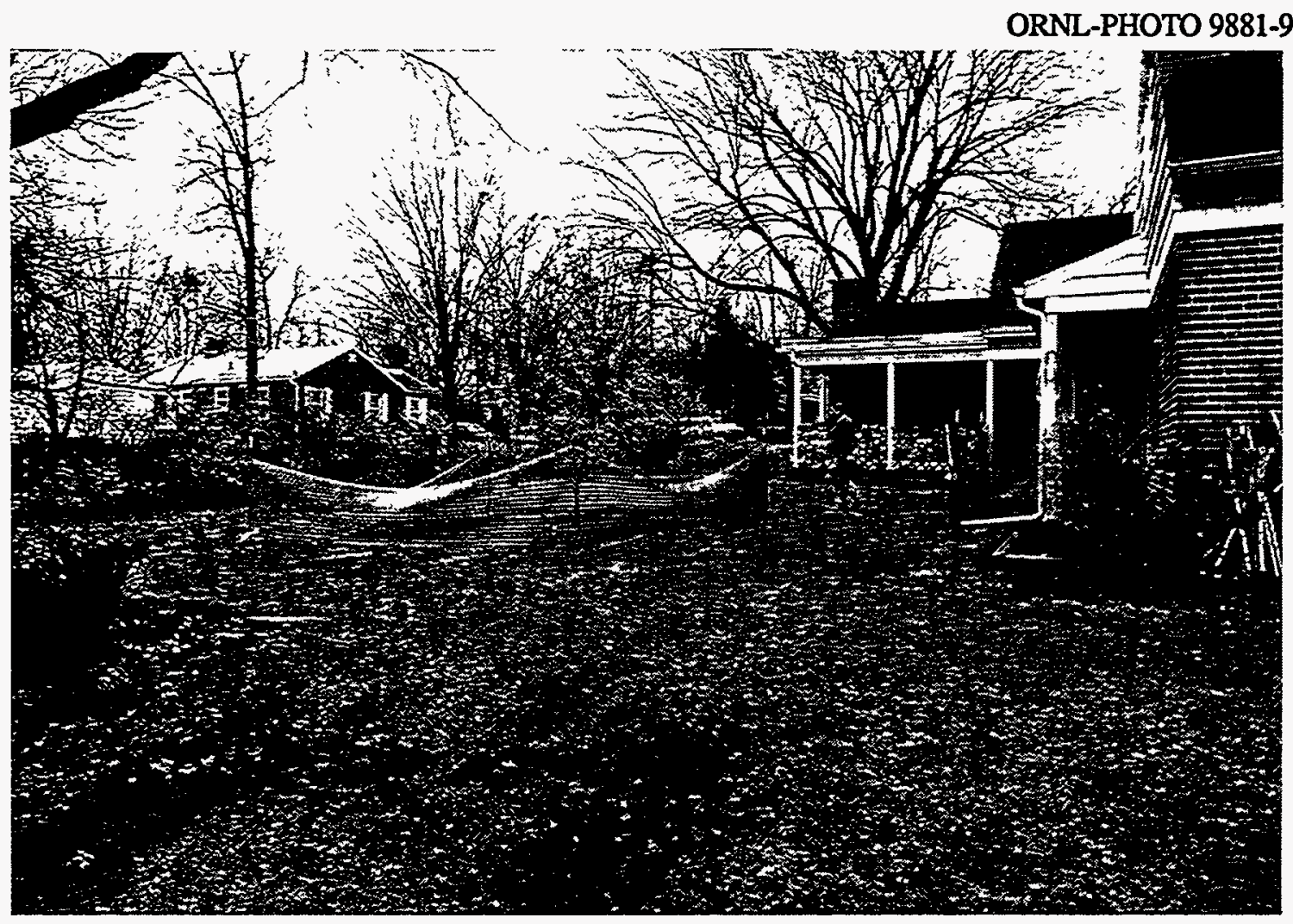

Fig. 8. Photograph showing excavated areas in the south yard at 525 S. Main Street. 


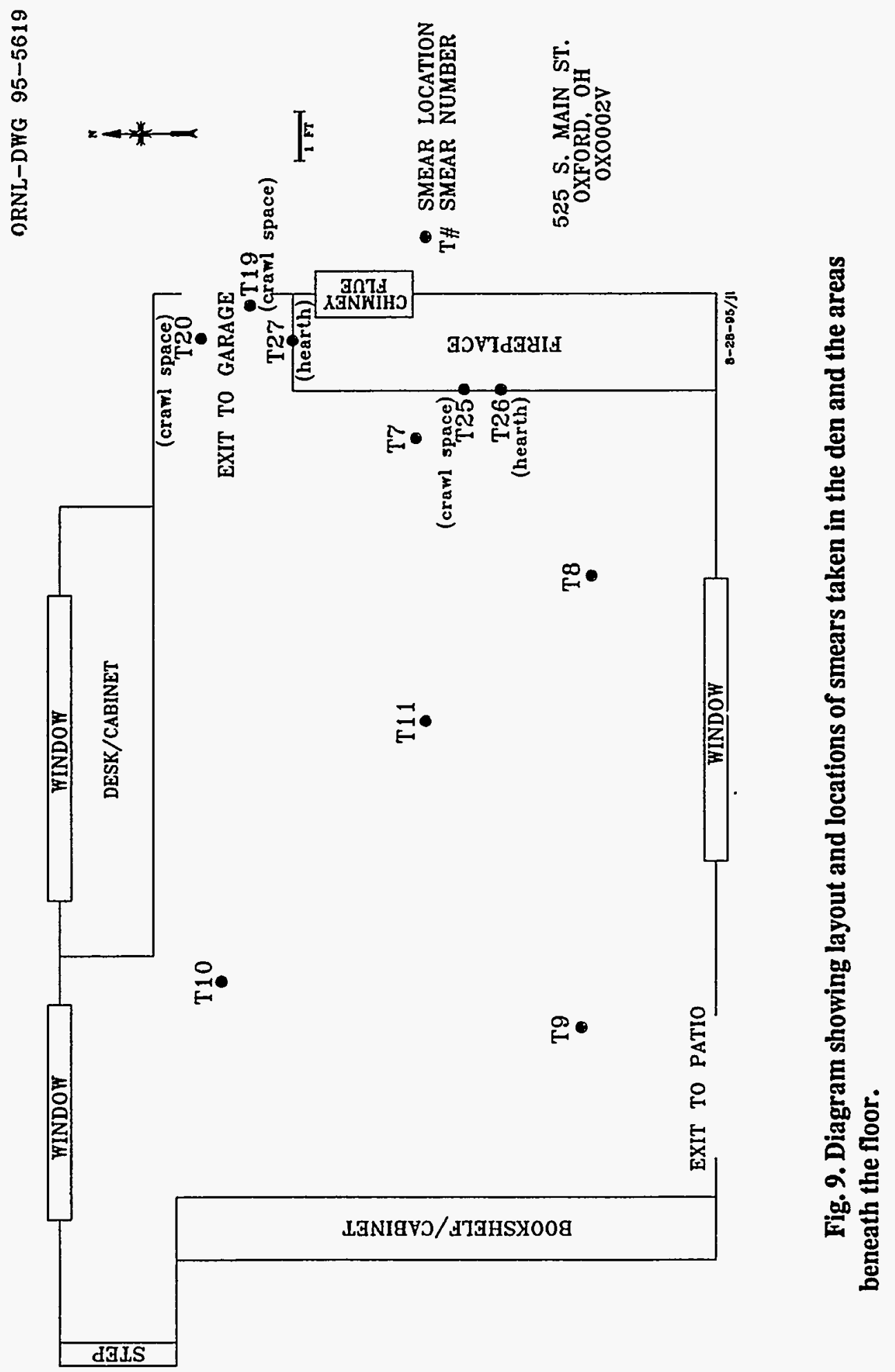


ORNL-DWG 95-5616

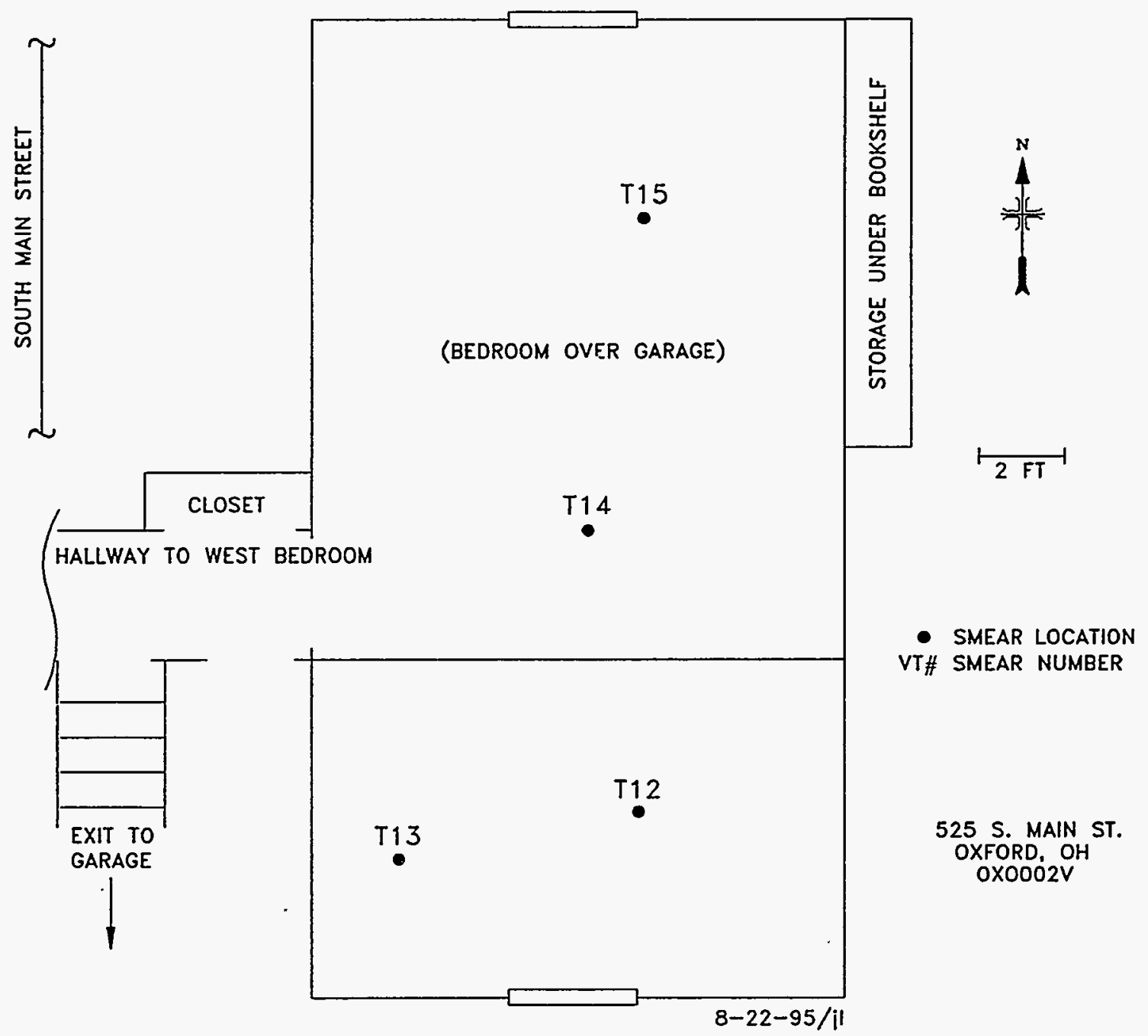

Fig. 10. Diagram showing layout and locations of smears taken in the east bedroom area. 


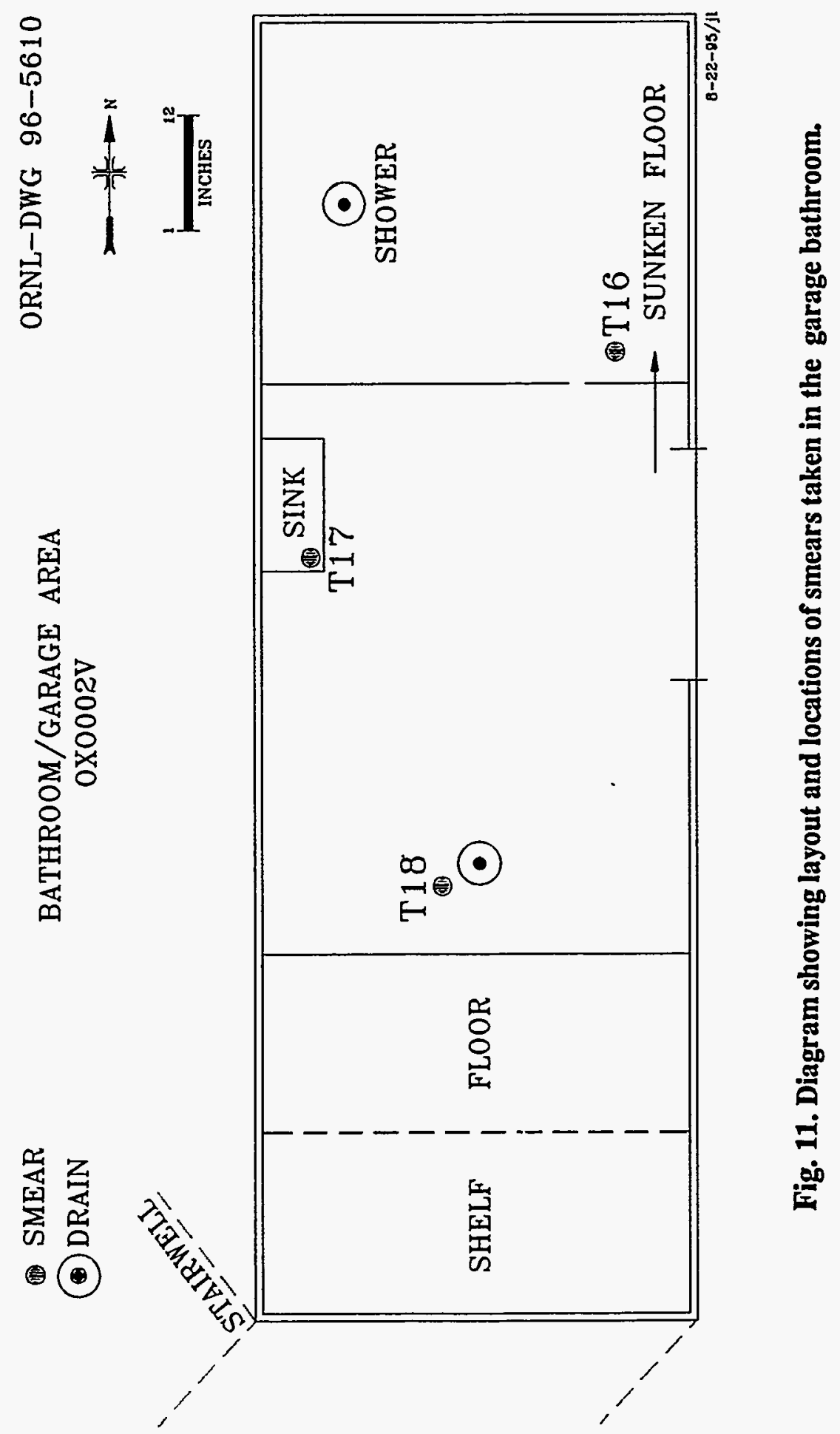


Table 1. Applicable guidelines for protection against radiation (Limits for uncontrolled areas)

\begin{tabular}{lcc}
\hline Mode of exposure & Exposure conditions & Guideline value \\
\hline Gamma radiation & $\begin{array}{c}\text { Indoor gamma level } \\
\text { (above background) }\end{array}$ & $20 \mu \mathrm{R} / \mathrm{h}^{a}$ \\
Total residual surface & $238 \mathrm{U}, 235 \mathrm{U}$, U-natural (alpha & \\
contamination ${ }^{b}$ & emitters) & \\
& or & \\
& Beta-gamma emitters $c$ & \\
& Fixed and removable & $15,000 \mathrm{dpm} / 100 \mathrm{~cm} 2$ \\
& Average & $5,000 \mathrm{dpm} / 100 \mathrm{~cm} 2$ \\
& Removable & $1,000 \mathrm{dpm} / 100 \mathrm{~cm}^{2}$ \\
& Maximum dose rate in any & $1.0 \mathrm{mrad} / \mathrm{h}$ \\
\hline
\end{tabular}

aThe $20 \mu \mathrm{R} / \mathrm{h}$ shall comply with the basic dose limit $(100 \mathrm{mrem} / \mathrm{yr})$ when an appropriate-use scenario is considered.

bDOE surface contamination guidelines are consistent with NRC Guidelines for Decontamination at Facilities and Equipment Prior to Release for Unrestricted Use or Termination of Licenses for By-Product, Source, or Special Nuclear Material, May 1987.

cBeta-gamma emitters (radionuclides with decay modes other than alpha emission or spontaneous fission) except $90 \mathrm{Sr}, 228 \mathrm{Ra}$, $223 \mathrm{Ra}, 227 \mathrm{Ac}$, $133 \mathrm{I}, 126 \mathrm{I}, 125 \mathrm{I}$.

Sources: Adapted from U. S. Department of Energy, Radiation Protection of the Public and the Environment, DOE Order 5400.5, April 1990 and U.S. Department of Energy, Guidelines for Residual Radioactive Material at FUSRAP and Remote SFMP Sites, Rev. 2, March 1987; and U.S. Department of Energy Radiological Control Manual, DOEN5480.6 (DOE/EH-256T), June 1992. 


\section{Table 2. Background radiation levels and concentrations of selected radionuclides in soil samples taken near \\ Oxford, Ohio}

\begin{tabular}{ccc}
\hline \multirow{2}{*}{$\begin{array}{c}\text { Type of radiation measurement } \\
\text { or sample }\end{array}$} & \multicolumn{2}{c}{$\begin{array}{c}\text { Radiation level or radionuclide } \\
\text { concentration }\end{array}$} \\
\cline { 2 - 3 } & Range & Average \\
\hline $\begin{array}{c}\text { Gamma exposure rate at } 1 \mathrm{~m} \text { above } \\
\text { ground surface }(\mu \mathrm{R} / \mathrm{h})^{a}\end{array}$ & $6-9$ & 8 \\
Concentration of radionuclides & & \\
in soil (pCi/g dry wt) $b$ & & 1.3 \\
238U & & 1.9 \\
226Ra & & 0.89 \\
$232 \mathrm{Th}$ & $1.0-2.5$ & \\
\end{tabular}

aResults of measurements taken at three locations near Oxford, Ohio.

$b$ Results of analysis of soil samples obtained from three locations near Oxford, Ohio.

Source: T. E. Myrick, B. A. Berven, and F. F. Haywood, State Background Measurements Taken During 1975-1979, ORNL/TM-7343, November, 1981. 
Table 3. Results of radionuclide analysis of soil samples collected from the property at 525 South Main Street, Oxford, Ohio

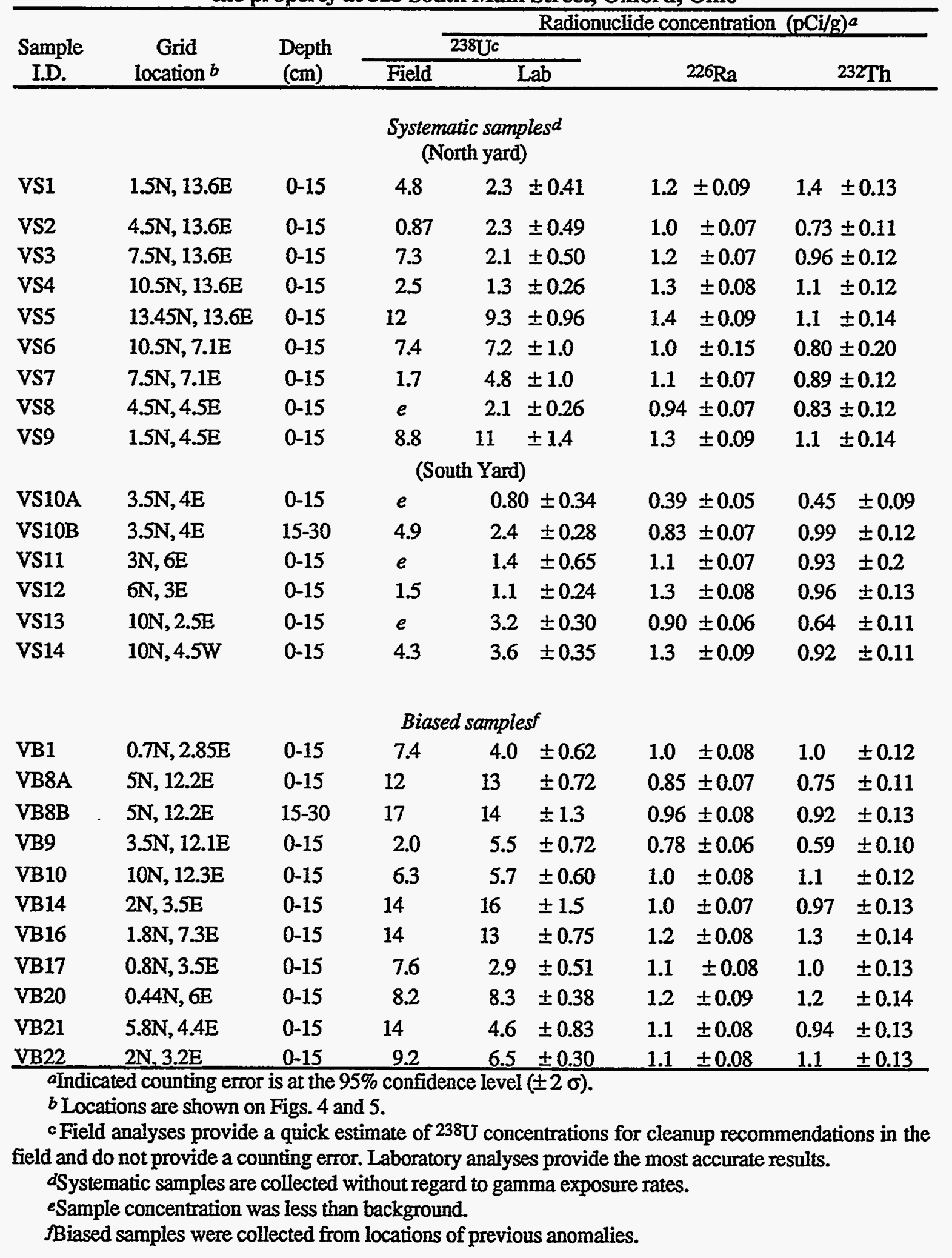


Table 4. Results of analysis of smear samples collected from indoor surfaces in the residence at 525 S. Main Street, Oxford, Ohio

\begin{tabular}{|c|c|c|c|c|}
\hline \multirow[b]{2}{*}{$\begin{array}{l}\text { Sample } \\
\text { ID }\end{array}$} & \multirow[b]{2}{*}{ Locationa } & \multirow[b]{2}{*}{$\begin{array}{c}\text { Location } \\
\text { detail }\end{array}$} & \multicolumn{2}{|c|}{ Removable contamination } \\
\hline & & & $\begin{array}{c}\text { Alpha } \\
(\mathrm{dpm} / 100 \mathrm{~cm})^{b}\end{array}$ & $\begin{array}{c}\text { Beta-gamma } \\
\left(\mathrm{dpm} / 100 \mathrm{~cm}^{2}\right) \mathrm{c}\end{array}$ \\
\hline $\mathrm{T} 7$ & Den & Floor & $<\mathrm{MDA}$ & $<M D A$ \\
\hline T8 & Den & Floor & $\angle \mathrm{MDA}$ & $<\mathrm{MDA}$ \\
\hline T9 & Den & Floor & $<\mathrm{MDA}$ & $<\mathrm{MDA}$ \\
\hline T10 & Den & Floor & $\angle M D A$ & $<M D A$ \\
\hline T11 & Den & Floor & $\angle \mathrm{MDA}$ & $<\mathrm{MDA}$ \\
\hline $\mathrm{T} 12$ & $\begin{array}{l}\text { Bedroom over } \\
\text { garage }\end{array}$ & Floor & $\angle M D A$ & $<M D A$ \\
\hline T13 & $\begin{array}{l}\text { Bedroom over } \\
\text { garage }\end{array}$ & Floor & $\angle \mathrm{MDA}$ & $<\mathrm{MDA}$ \\
\hline T14 & $\begin{array}{l}\text { Bedroom over } \\
\text { garage }\end{array}$ & Floor & $\angle \mathrm{MDA}$ & $<\mathrm{MDA}$ \\
\hline T15 & $\begin{array}{l}\text { Bedroom over } \\
\text { garage }\end{array}$ & Floor & $<\mathrm{MDA}$ & $<\mathrm{MDA}$ \\
\hline T16 & $\begin{array}{c}\text { Garage } \\
\text { bathroom }\end{array}$ & $\begin{array}{l}\text { Shower } \\
\text { floor }\end{array}$ & $\angle M D A$ & $<M D A$ \\
\hline $\mathrm{T} 17$ & $\begin{array}{c}\text { Garage } \\
\text { bathroom }\end{array}$ & Floor & $\angle M D A$ & $<\mathrm{MDA}$ \\
\hline T18 & $\begin{array}{c}\text { Garage } \\
\text { bathroom }\end{array}$ & Floor & $\angle \mathrm{MDA}$ & $<\mathrm{MDA}$ \\
\hline
\end{tabular}

$a$ Locations of smears are shown on Figs. 9 through 11.

$b$ The instrument-specific minimum detectable activity for removable alpha activity levels is $10 \mathrm{dpm} / 100 \mathrm{~cm}^{2}$.

cThe instrument-specific minimum detectable activity for beta-gamma activity levels is $200 \mathrm{dpm} / 100 \mathrm{~cm}^{2}$. 


\section{INTERNAL DISTRIBUTION}

\author{
1. K. J. Brown \\ 2-4. R. F. Carrier \\ 5. R. D. Foley \\ 6. R. C. Gosslee \\ 7. C. A. Johnson \\ 8-9. M. E. Murray \\ 10. P. T. Owen \\ 11-12. D. E. Rice \\ 13. D. A. Roberts \\ 14. R. E. Swaja
}

\author{
15. R. E. Rodriguez \\ 16. M. S. Uziel \\ 17. J. K. Williams \\ 18. Central Research Library \\ 19-21. Laboratory Records \\ 22. Laboratory Records - RC \\ 23. ORNL Patent Section \\ 24. ORNL Technical Library, Y-12 \\ 25-30. MAD Records Center
}

\section{EXTERNAL DISTRIBUTION}

31. D. G. Adler, Former Sites Restoration Division, Oak Ridge Field Office, U.S. Department of Energy, P.O. Box 2001, Oak Ridge, TN, 37831-8723

32. W. L. Beck, ORISE, E/ESD, 1299 Bethel Valley Road, Oak Ridge, TN 37831

33. J. J. Fiore, Director, Office of Eastern Area Programs, Office of Environmental Restoration, Cloverleaf Bldg. (EM-24) U.S. Department of Energy, 19901 Germantown Rd., Germantown, MD 20874-1290

34. FUSRAP Document Center, Science Applications International Corporation, P.O. Box 2501, 301 Laboratory Road, Oak Ridge, TN, 37831

35. Albert Johnson, Program Manager, Formerly Utilized Sites Remedial Action Program, U.S. Department of Energy, Cloverleaf Bldg., 19901 Germantown Rd., Germantown, MD 208741290

36-41. K. R. Kleinhans, Y-12 Site Health Physics Supervisor, MK-Ferguson of Oak Ridge Co., P.O. Box 2011, Bldg. 9703-15, Oak Ridge, TN 37831-2100

42. L. K. Price, Director, Former Sites Restoration Division, Oak Ridge Field Office, U.S. Department of Energy, P.O. Box 2001, Oak Ridge, TN 37831-8723

43. Jack Russell, 12850 Middlebrook Road, Suite 210, Germantown, MD 20874

44. A. G. Toddings, FUSRAP Project Administrator Bechtel National, Inc., FUSRAP Department, Oak Ridge Corporate Center, 151 Lafayette Drive, P. O. Box 350, Oak Ridge, TN 37831-0350

45-47. W. Alexander Williams, Designation and Certification Manager, Division of Off-Site Programs, Office of Eastern Area Programs, Office of Environmental Restoration, Cloverleaf Bldg. (EM421), U.S. Department of Energy, 19901 Germantown Rd., Germantown, MD 20874-1290

48-49. Office of Assistant Manager, Energy Research and Development, DOE Oak Ridge Operations, P.O. Box 2001, Oak Ridge, TN 37831-8600

50-52. Office of Scientific and Technical Information, DOE, P.O. Box 62, Oak Ridge, TN 37831 
